\title{
Skitse til en bestemmelse af overgan- gen fra II. til III. kapitelbind - eller et forsøg på ud fra kapitallogikken at be- stemme profitformens opdukken efter reproduktionsproblematikken i den marxske kapitalfremstilling.
}

\author{
Hans-Jørgen Schanz
}

I

At stille problemet om overgangen fra II. til III. Kapitalbind udtrykker en intention om at fastholde nødvendigheden af en immanentisk rekonstruktion af kapitalbegrebet, eller sagt med andre ord: at arbejde ud fra den marxske fremstillingsintention (Darstellungsintention) ${ }^{1}$. Fremstillingen har to elementer, som ikke må forveksles eller identificeres, omend de ikke existerer uden formidling: a) fremstillingen forstået som værdiens prasentationsform på et givet kapitallogisk udviklingstrin (f.ex. værdisubstansens form for tilsynekomst som værdiform, eller vareproduktets værdis tilsynekomst som produktionspris), og b) fremstillingen forstået som kapitalbegrebets afledning og udvikling in toto (eller som en 'strækning' af denne totale afledning). Man ser, at de to fænomener hænger sammen: hvis ikke værdien realiter havde kvalitet af at konstituere forskellige præsentationsformer på forskellige trin eller i forskellige sammenhænge, så ville en immanentisk rekonstruktiv fremstillingsform over for kapitalbegrebet enten være ubegrundet eller kun begrundet ud fra en eller anden modisk (omend den kan være altmodisch) facon de parle vedrørende en ontologisk dialektiksubstans. De to alternativer er forskningslogisk identiske, idet de begge undlader at stille problemet vedrørende kapitallogikkens specifitet. Dette har blandt andet effekter på historieteorien: kapitalismen (eller det 'sociale' kapitalforhold) gøres forskningsautomatisk til et specialtilfælde under en metafysisk given historisk materialisme.

1. Til den marxske selvforståelse omkring den ideelle fremstillingsform se f.ex. brevet til Ferdinand Lasalle, 22.2.-1858, findes bl.a. i MEW bind 29, pg. 549-552, endvidere i »Briefe über 'Das Kapital'«, Erlangen 1972, pg. 80-81. 
Men selv om det således gælder, at kapitalbegrebets specifikke fremstillingsform er ubegrundelig uden kapitalens specifikke præsentationsform, så er de to fænomener ikke desto mindre adskillelige. Således kan man beskæftige sig med punktuelt udvalgte (for deh sags skyld gerne exemplariske) fænomenkomplekser for indenfor disse at stille spørgsmålet vedrørende kapitalens præsentationsform. F.ex. kan man stille spørgsmålet om, hvorledes det går til, at arbejdslønnen tager sig ud (præsenterer sig) som betaling for arbejdet (og ikke, kategorialt set, arbejdskraften), eller hvorledes det går til, at kapitalforholdet på overfladen præsenterer sig) således, at det ser ud som om der existerer tre selvstændige rigdomskilder (værdikilder, da rigdommen netop under kapitalismen altid foreligger i form af værdi): arbejde, jord og kapital².

Karakteristisk for denne unders $\varnothing$ gelse af præsentationslogikken er det, at den så godt som altid kommer til at identificere dechiffreringen af de specifikke præsentationsmodi med kapitalbegrebets fremstilling. Men herved falder kapitalens historie- og reproduktionsteoretiske konsekvenser under bordet: kapitalen er ikke længere en real overgribende bevægelse, men en præsentationslogik (der i høj grad er historieløs), som, hvor meget end dens forfægtere erklærer sig frigjorte af en traditionel ideologikritik, ikke desto mindre blot udgør en art radikaliseret ideologikritisk måde at recipere (og anvende) kritikken af den politiske $\varnothing$ konomi på. Den klassiske og i et vist omfang også den nyere Frankfurterskole er her et godt exempel ${ }^{3}$. Men også den franske strukturale marxisme kan udsættes for en sådan kritik. Jeg har i efterskriften til Rancieres artikel: »Kritikbegrebet og kritikken af den politiske $\varnothing$ konomi $\ll^{4}$ gjort opmærksom på denne falske identifikation af fremstillingslogik (afledningslogik) og præsentationslogik.

Det blev nævnt, at identifikationen fører til en blindhed overfor historieteoretiske og reproduktionsteoretiske problemstillinger, endvidere kan identifikationen føre til en identitetslogisk projektion af kapitalens udbredelsesfacon: idet man undlader at stille spørgsmål vedrørende på hvilket niveau i kapitalbegrebets fremstilling det er, at vi undersøger en given prasentationsmodus, kommer kan

2 Se f.ex. det syvende afsnit i Kapitalens III. bind (Revenuen og dens kilder). I moderne vækstteoretiske og herunder uddannelses- og forsknings $\varnothing$ konomiske teoridannelser tilføjes yderligere mindst to 'rigdomskilder': videnskab og kvalifikation. En god prolegomena til de moderne vækstteoretiske teoridannelsers effekter på f.ex. uddannelses- og forskningsteorien findes $\mathrm{i} »$ Economics of Education « I og II, udgivet af M. Blaug, Penguin Books, 1971.

3 Det kan dog være problematisk at fremhæve Frankfurterskolen: dels fordi denne, ser vi bort fra Habermas' kritik af Marx, i meget ringe grad explicit påberåber sig Marx (omend der hos Horkheimer og Adorno er en overordentlig kraftig anvendelse af begreber fra den marxske teori), og dels fordi denne skole vel i højere grad (i sin selvforståelse såvel som i sin overtagne terminologi) relaterer sig til et alment og egentlig uspecificeret begreb for den historiske materialisme end den tager udgangspunkt i kritikken af den politiske økonomi. Når Frankfurterskolen alligevel i et vist omfang kan tjene som illustration, så hænger dette sammen med dens overtagelse (omend dette heller ikke nævnes nogen steder) af den unge Lukacs kritiske marxisme fra Geschichte und Klassenbewusstsein.

4 Jacques Ranciere: »Kritikbegrebet og kritikken af den politiske økonomi«, Modtryk 1973. Efterskriften: »Abstraktion og udvikling«, pg. 137-159. 
implicite automatisk til at sætte en overalt identisk gældende udbredelseslogik ${ }^{5}$ : man tror f.ex. at værdiens udbredelseslogik, således som denne kommer til udtryk i dens præsentationslogik, er identisk for værdiformen og profitformen. Imidlertid skulle det være indlysende, at man herved 'positiverer' og hypostaserer subsumtionslogikken. Når Marx i brevet til Engels siger: ${ }^{6}$

»Ideologismen slår igennem, og den dialektiske metode bliver anvendt forkert. Hegel har aldrig kaldt subsumtionen af en masse af 'tilfalde' ('cases') under et generelt princip for dialektik«,

så skulle det være evident, at dette forhold, hvor man subsumerer en masse af tilfælde under 'a general principle' ikke bliver bedre af, at det generelle princip nu nominalistisk kaldes kapitalen og de mange 'tilfælde' kapitalelementer. Kun sammentænkningen af fremstillingslogik og nu specifikke prasentationsmodi og subsumtionsformer kan garantere en uforkortet tilegnelse af kritikken af den politiske $\emptyset$ konomi, og dermed sikre dens revolutionære kritikkraft. Bl.a. vil en sådan tilgang til kritikken af den politiske $\varnothing$ konomi alene kunne sikre en uforkortet tilgang til det historisk centrale problem omkring samfundsmæssiggørelsesbestemmelsernes dobbeltkarakterer, dobbeltkarakterer, som tillige altid er historisk specifikke.

\section{II}

Men herved er fremstillingsproblemet i Kapitalen blevet pointeret: vi er tilbage ved udgangspunktet og det, som denne artikel egentlig skulle handle om, nemlig overgangen fra II. til III. Kapitalbind.

Vi ved, at Marx kun nåede at udgive Kapitalens I. bind, og at manuskripterne til de efterfølgende bind indeholder mange 'huller', især findes disse i overgangsleddene: såvel indenfor de forskellige kapitalbind som i overgangen

5 Det idag næsten klassiske exempel (som i postmarxismen dukker op i Lukacs' »Geschichte und Klassenbewusstsein«, 1923 for første gang) er fetishismeproblematikken. I Kapitalens første kapitel hedder det sidste afsnit »Varens fetishkarakter og dens hemmelighed «. Marx gør her opmærksom på hvilke effekter pengeformen (og herunder værdiformen) har på reifikationen af de samfundsmæssige forhold og herigennem på bevidsthedens fetisherede orienteringsform indenfor en sådan samfundsmæssig sammenhæng. Imidlertid kan den reifikation (og fetishisme) som dér påpeges som en latens, endnu ikke siges at have den samfundsmæssige status, som den tillægges, hvis man tror, at reifikationens kvalitet fra nu af er givet, og der i den videre udvikling blot er tale om en kvantitativ tilvækst af reifikation. Først med kapitalbegrebets udvikling frem til den rentebærende kapital (se III. Kapitalbind femte afsnit), hvor den enkelte vare (den rentebærende pengevare) opstår, er reifikationssammenhængen fuldbyrdet: i samtlige sammenhænge hidtil har værdien (og dermed valoriseringen) været formidlet explicite over brugsværdierne, og herved har reifikationen været begrænset til 'blot' at udgøre funktionslogikken for det samfundsmæssige forhold, og værdien har ikke været en 'ting', der lukket i sig selv blokerede for forståelsen af det samfundsmæssige forhold, som bærer den. Det sker med den rentebærende kapital. Først her er alle formidlingssammenhænge kappet over.

6 Marx' brev til Engels fra d. 9.-12.-1861, MEW bind 30, pg. 207. 
mellem disse. Vi skal her koncentrere os om overgangen fra II. til III. Kapitalbind, alligevel er det af betydning kort at komme ind på forholdet mellem I. og II. Kapitalbind, om ikke for andet så for at vise plausibiliteten af en sådan problematisering.

Mellem de to Kapitalbind (I. og II.) er der ingen overgang, bind II starter med det allerede overgangne: vi går fra kapitalens umiddelbare produktonsproces (I. bind) til dens cirkulations- eller kredsløbsproces. Imidlertid viser det sig ved nærmere eftersyn, at der i Grundrisse der Kritik der politischen Ökonomie findes et afsnit (pg. 305-325) ${ }^{7}$, som i det mindste intenderer at levere denne overgangsform.

I mit arbejdspapir »Overgangen fra kapitalens produktionsproces til dens cirkulationsproces $\ll^{8}$ vises, at kapitalbindene her er mangelfulde samt, at det grosso modo er muligt at rekonstruere overgangen. Vi skal her kort se på et par af problemerne i dette arbejdspapir for at demonstrere, hvor vigtigt det er, at fastholde kapitalbegrebets udvikling.

I Rosdolskys iøvrigt helt fortræffelige kommentarværk til Grundrisse ${ }^{9}$ findes en dobbeltfejl vedrørende vurderingen af siderne 305-325 i Grundrisse. For det første bestemmer han disse sider som blot: ${ }^{10}$

»en exkurs (...) der strengt taget fører ud over rammerne for den abstrakte analyse af cirkulationsprocessen og de deri opdukkede formbestemmelser; alligevel må denne exkurs anses for et kærkomment supplement til denne analyse«.

Fejlen er her, at Rosdolsky tror, at der blot er tale om en exkurs på trods af, at Marx netop her forsøger at tænke overgangen fra produktionen til cirkulationen som en immanentisk. For det andet er Rosdolskys fremstilling mangelfuld derved, at den lader som om overgangen fra produktion til cirkulation ikke er nogen overgang, som selv må afledes af kapitalen, men som tilstrækkeligt skulle være begrebet i form af det allerede overgangne. Dette er egentlig underligt, hvis man tager i betragtning, at Rosdolsky var den første i den nye 'kapitallogiske' tradition, som netop gjorde opmærksom på den immanentiske læsning af kritikken af den politiske økonomi.

Ved Rosdolskys tilgang overses to forhold ${ }^{11}$ : for det første at overgangen fra produktion til cirkulation tillige er cirkulationssfærens subsumtion under kapi-

7 I »Grundris«, Rhodos udvalget, findes der kun et par brokker af siderne 305-325 i Grundrisse, nemlig pg. 159-163 og 164-169. Dette udvalg er uheldigt i denne her sammenhæng, idet det overhovedet ikke tillader en påvisning af, at afsnittet, som det er taget fra, udgør et hele, og til og med et meget centralt hele, da det er det eneste sted overhovedet, hvor Marx direkte behandler overgangsformen fra produktion til cirkulation.

8 H-J. Schanz: »Overgangen fra kapitalens produktionsproces til dens cirkulationsproces«, stencilat, idehistorisk institut, Århus Universitet, september 1972.

9 Roman Rosdolsky: »Zur Entstehungsgeschichte des Marxschen 'Kapital'. Der Rohentwurf des Kapital 1857-1858«, Frankfurt am Main 1968.

10 Rosdolsky, op. cit. pg. 374.

11 Disse forhold er udførligt fremstillet i »Overgangen fra...«, her nøjes vi med resultaterne samt konsekvenserne. 
talen. I det 'øjeblik' hvor kapitalen fra produktionssfæren går ind i cirkulationssfæren, idet den etablerer sit reproduktive kredsløb, ophører cirkulationssfæren med at være en selvstændig, kun af værdibytningen afhængig sfære: den er nu integreret i kapitalen, et moment i denne. Dette betyder f.ex., at Sohn-Rethelske synthesisteorier kapitallogisk kan afvises: fra det 'øjeblik', hvor produktionen griber over i og herved subsumerer cirkulationen som et moment i kapitalens kredsløb (hvilket præciseres i II. Kapitalbind) er kapitalens reproduktionslogik alene det synthesiskonstituerende indenfor kapitalismen, cirkulationen er blot et moment, og under ingen omstændigheder det moment, som alene sætter kapitalismens syntheseform ${ }^{12}$.

At man igennem denne rekonstruktion af overgangen, hvor cirkulationen subsumeres under kapitalbegrebet, ikke blot bliver i stand til at kritisere SohnRethelske teorier, skulle være indlysende. Blandt andet vil denne rekonstruktion være at a nse for en af betingelserne for en virkelig marxistisk kritik af finanskapitalismeteorierne (hvadenten disse nu foreligger i Hilferdingske eller Baran/ Sweezyske udgaver).

For det andet overses ved den 'problembenægtende' rekonstruktion, at de specifikke modsætninger (især relateret til de såkaldte realisationsfænomener), som kommer til eller opstår i cirkulationsfæren, »er immanente grænser i kapitalen selv, grænser som selv falder sammen med kapitalens væsentligste begrebsbestemmelser $\ll^{13}$.

At dette sidste, hvor altså netop cirkulationssfæren bestemmes som et begrebsmoment ved kapitalbegrebet, er af alt overskyggende betydning for en kritik af de forskellige socialdemokratiske distributionsteoretiske varianter, bør vel næppe underbygges her.

Når Marx i Kapitalens III. bind siger: ${ }^{14}$

»Betingelserne for den umiddelbare udbytning og for dens realisation er ikke identiske. Der er skilt fra hinanden, ikke blot i tid og sted, men også begrebsmæssigt. Nogle af dem er kun begrænset af samfundets produktionskapicitet, de øvrige af proportio-

12. Alfred Sohn-Rethel har bl.a. i »Geistige und körperliche Arbeit«, Frankfurt/M 1970, fremsat denne synthesistanke, som i al korthed går ud på, at sålænge kapitalismen existerer vil det eneste synthesis (sammenhængsdannende) konstituerende element være byttesfæren, altså cirkulationen. Den autonomi, som cirkulationen her tillægges, er pure skin, hvilket bl.a. kan vises ved at rekonstruere overgangen fra produktion til cirkulation, således som dette forhold behandles i Grundrisse. Omend vi ikke her skal gå nærmere ind på dette forhold, så kan det nævnes, at Sohn-Rethels specielle synthesisteori kapitallogisk egentlig sagligt må siges at være bundet til II. og III. Internationales kriseteorier. Karakteristisk for disse er bl.a. den udifferentierede snak om kapitalismen som en anarkisammenhæng, som blot holdes sammen igennem cirkulationssfærens relationer. Se hertil Engels i Anti-DÜHRING. MEW bind 20, pg. 258, pg. 225; endvidere hans kritik af det socialdemokratiske programudkast 1891 (det såkaldte Erfurterprogram) i MEW 22, pg. 231. Engels grundlægger her (og andre steder) II. og III. Internationales kapitalteorier.

13. Pg. $9 \mathrm{i} »$ Overgangen fra kapitalens produktionsproces til dens cirkulationsproces«, sidste del af citatet er fra Grundrisse pg. 318.

14. Kapitalen, 3 bog 2, pg. 322, København 1972. 
naliteten mellem de forskellige samfundsgrene og af samfundets konsumkraft ${ }^{15}$. Denne sidste er imidlertid hverken bestemt af produktionskapacitetens absolutte størrelse eller af konsumkraftens absolutte størrelse, men af konsumkraften på basis af antagonistiske distributionsforhold, som reducerer forbruget blandt den store masse i samfundet til et minimum, der blot svinger inden for mere eller mindre snævre grænser«,

så er det vigtigt, at fastholde, at de specifikke modsætninger, som findes omkring realisationsfænomenerne i cirkulationssfæren selv er sat af kapitalforholdet: at de er nogle af kapitalens specifikke former for tilsynekomst i cirkulationssfæren. For at dette skal være muligt, må cirkulationssfæren derfor selv vises at være et moment i kapitalen, hvilket netop sker i Grundrisse ${ }^{16}$.

\section{III}

Medens vi ved overgangen fra I. til II. bind kunne anvende siderne 305-325 i Grundrisse som et systematisk fors $\emptyset \mathrm{g}$ fra Marx på at tænke denne overgang, så er problemet vanskeligere, hvad angår overgangen fra II. til III. bind, idet vi her (ser vi bort fra to sider i Grundrisse, nemlig pg. 631-632, som selv er nok så vanskelige og i hvert fald yderst interpretationsbehøvende) stort set er tvunget til selv at rekonstruere denne overgang. Det vil sige dens nødvendighedsform.

I første omgang kan vi stille følgende udgangsspørgsmål: hvorledes er overgangen som overgang (og ikke bare i form af det allerede overgangne) begrundet og fremstillet hos Marx, Rosdolsky og Reichelt ${ }^{17}$ ?

II. Kapitalbind slutter med de såkaldte reproduktionsskemaer, nærmere bestemt problemerne omkring ligevægtsbestemmelserne for en simpel og en udvidet reproduktion. Ligevægtsbestemmelserne søges dér oparbejdet ud fra a) den stoflige reproduktion, b) den værdimæssige og c) den ækvivalentformidlede. Karakteristisk for analysen er, at der endnu ikke opereres med selvstændiggjorte enkeltkapitaler ${ }^{18}$ eller mere alment en selvstændiggjort penge- og handelskapital: den gesamtkapi-

15. Rhodos' Kapitaloversættelse er her upræcis. Hos Marx står der helt utvetydigt: »Den ene art af betingelser (nemlig betingelserne for exploitationen, H-JS) er kun begrænset af samfundets produktivkraft, den anden art af betingelser er begrænset af proportionaliteten mellem de forskellige produktionsgrene og af samfundets konsumkraft«, MEW bind 25, pg. 254.

16. I det omtalte afsnit i Grundrisse (pg. 305-325) viser Marx netop, at kapitalens subsumtion af cirkulationen under sig implicerer de antagonistiske distributionsforhold i denne.

17. Helmut Reichelt: »Zur logischen Struktur des Kapitalbegriffs bei Karl Marx«, Frankfurt/M 1970. Når vi her trækker Rosdolsky og Reichelt frem, så fordi det er disse som først og fremmest har pointeret nødvendigheden af en immanentisk rekonstruktion af kritikken af den politiske $\emptyset$ konomi. Derfor må vi hos disse forvente et svar på det problem vi stiller.

18. Vi kommer senere ind på, at den reproduktive mulighedsbetingelse for enkeltkapitaler er profitformen. Da denne netop endnu ikke findes i II. Kapitalbind, hvor vi altså endnu befinder os indenfor das Kapital im Allgemeinen, ses også, at den kapital vi har med at gøre, er den almene, endnu ikke opsplittede i selvstændiggjorte dele. 
tal, hvis reproduktionsbetingelser, der spørges om, er udelukkende den vare- og merværdiproducerende, som altså endnu ikke er spaltet op i enkeltkapitaler.

Medens I. Kapitalbind primært beskæftiger sig med den umiddelbare produktionsproces, som ikke må identificeres med det generelle i enhver enkeltkapitals produktionsproces, omend der måtte være (og også er) en lang række formelle identiteter de to imellem, så beskæftiger II. Kapitalbind sig med kapitelens kredsløbsbevægelser som enhed af produktion og cirkulation. I et brev til Engels fra d. 30. april 1868 beskriver Marx det videre forløb udover I. Kapitalbind. Det hedder i tilknytning hertil: ${ }^{19}$

»... i bog I nøjes vi med at antage, at når der i valoriseringsprocessen opstår 110 pund af 100, så forefindes elementerne til disses nye omsætning på markedet. Men nu undersøger vi betingelserne for denne forefinden, altså den samfundsmæssige sammenknytning (Verschlingung) af de forskellige kapitaler, kapitaldele og revenu $(=\mathrm{m})$ «

II. Kapitalbind er hermed i høj grad at bestemme som den nødvendige overgangsforbindelse for den endelige præcisering af 'die Bedingungen dieses Vorfindens'. I tilknytning til indledningen til afsnittet om reproduktionsafsnittet (i II. Kapitalbind) siges, at nu, hvor vi skal se på en samlet reproduktiv kapital og hermed på betingelserne for forefindelsen af de reproduktive betingelser, da er det ikke længere tilstrækkeligt at betragte forholdet rent værdimæssigt, eller værdimæssigt plus et element som hedder materialitet som sådan (hvadenten denne materialitet hedder produkt eller arbejdsproces som sådan). I første Kapitalbind er 'brugsværdierne' eller materialiteterne i højeste grad marginalbetingelser forstået på den måde, at deres existens ganske vist pointeres ${ }^{20}$, men dette sker ikke konkret eller specifikt, de er der, men deres materielle og historiske form spiller ikke explicite ind ${ }^{21} 22$.

19. Briefe über das Kapital, pg. 168.

20. Hvis ikke materialiteten (omend kun som marginalbetingelse) blev pointeret hele das Kapital igennem, så ville dens grundlæggende distinktion mellem arbejdets dobbeltkarakter og arbejdsproduktets (varens) dobbeltform være umulig.

21. Alligevel findes, omend dette aspekt ikke fremhæves i denne form, der i I. Kapitalbind flere yderst vigtige formøkonomiske bestemmelser, som er utænkelige uden som også båret af formforandringer i materialiteten: f.eks. er den afgørende distinktion mellem arbejdets formelle og dets reelle subsumtion under kapitalen realiter utænkeligt uden som også båret af en forandring i arbejdsprocessens materialitet (overgangen fra en manufakturel til en letindustriel teknologi). Imidlertid sættes i kritikken af den politiske $\varnothing$ konomi den teknologiske materialitet i dens specifikke historicitet ikke i centrum. Derimod fokuseres der på nogle almene effekter, som disse materielle formforandringer implicerer i de $\varnothing$ konomiske formbestemmelser. For en socialistisk teoridannelse og analyse er det imidlertid af største betydning konkret og historisk specifikt at bestemme disse materielle formforandringer, da det er omkring disse at kapitalens samfundsmæssiggørelseseffekter historisk mest vigtigt slår igennem i en altid specifik dobbeltkarakter. Se H-J Schanz: »Nogle problemer omkring forholdet mellem væsenslogik og omgangslogik«, stencilat, I-dehistorisk institut, Århus Universitet, maj 1974.

22. Sml. udtalelserne omkring brugsværdiernes status i »Zur Kritik der politischen ökonomie«, MEW bind 13, og Grundrisse pg. 178-179; »Grundrids«, bind 1, pg. 166-167, Modtryk og Kurasje, Århus 1974. 
Dette aspekt, altså omkring materialitetsformernes formøkonomiske potenser, aktualiseres allerede explicite i den centrale distinktion mellem fix og flydende kapital (i II. Kapitalbind) som forudsætning for løsningen af problemet vedrørende den årlie merværdimasse i relation til de forskellige kapitaldeles omslagshastigheder. I gennemgangen af reproduktionsbetingelserne ser vi differentieringen indenfor materialitetsformerne som en helt afgørende forudsætning for logikken $\mathrm{i} »$ die Bedingungen dieses Vorfindens « af reproduktionsmuligheder.

III. Kapitalbind begynder med bestemmelser af kostprisen og profit, hvor bl.a. den vigtige distinktion mellem fix og flydende kapital atter dukker op. Der er i det mindste to forhold som karakteriserer åbningen af III. Kapitalbind: for det første siges der intet om, hvad kostprisen og profitten er »svar « på, eller sagt med andre ord og i forlængelse af det almene ledespørgsmål for rekonstruktionen her: hvilke modsigelser er profitformen og herunder kostprisen udtryk for? For det andet tager Marx tilsyneladende pludselig udgangspunkt i, hvad enkeltkapitalisten tænker og gør, når han definitorisk fastslår profittens opståen: han citerer Malthus for følgende udtalelse: ${ }^{23}$

»Kapitalisten forventer den samme fordel af alle dele af den kapital, han lægger ud«, og fastslår derefter: ${ }^{24}$

»Når man på denne måde forestiller sig merværdien som afkom af den udlagte totalkapital, får merværdien den forvandlede form af profit. En værdisum er Kapital, fordi den lægges ud for at afkaste en profit, eller profitten fremkommer, fordi en værdisum anvendes som kapital «

Endelig - og det er i denne her forbindelse det centrale - kunne man spørge: hvorledes ser den kapitallogiske udviklingsrelation ud, eller sagt med andre ord: hvad er det i selve reproduktionsproblematikken, som gør profitformen nødvendig som næste etape i fremstillingslogikken? Svaret på dette er ikke givet af Marx. Det er i tesen her, at der egentlig i overgangen fra II. til III. kapitalbind ligger et svar. Dette »svar « vil ikke bare have en æstetisk fremstillingslogisk statur (i betydningen: nu hænger det hele sammen), men det vil tillige sige noget om realforholdet mellem merværdi og profit, og hermed noget om kapitalens reproduktionslogik.

Heller ikke i Grundrisse er dette spørgsmål eller disse spørgsmål besvaret explicite. Imidlertid kunne man nu forledes til at tro, at spørgsmålene derfor var retorisk ligegyldige, især - som vi senere skal se - da de hverken stilles eller løses hos Rosdolsky og Reichelt. Man kunne da tro, at spørgsmålene var en effekt af den efterhånden meget omtalte kapitallogiske og akademiske sygdom. Dog kan man - og det må vi i første omgang ligitimere os igennem - stille det modspørgsmål, som lyder: hvordan går det til, at en så vigtig overgang som overgangen fra merværdi til profit i modsætning til samtlige andre formovergange (hvoraf de al-

23. Das Kapital III, MEW bind 25, pg. 46; Kapitalen 3. bog 1, pg. 47.

24. Das Kapital III, MEW bind 25, pg. 46; Kapitalen 3. bog 1, pg. 47. 
lerfleste endog har en langt mindre rækkevidde end denne her) slet ikke er nogen overgang, men et rent og skært spring ${ }^{25}$. Når man springer på denne måde, så er det også karakteristisk, at man springer over det ellers så afgørende spørgsmål om nødvendigheden af en overgang. Selv hvis man ville fastholde det uomgængelige $\mathrm{i}$ et sådant spring, så måtte man kunne begrunde dets nødvnendighed samt - og det er ikke helt ligegyldigt - nødvendigheden af dette spring netop på dette sted, sonst wird die dialektische Methode falsch angewandt. Lad os nu se på fremstillingen hos Rosdolsky og Reichelt.

\section{IV}

Hos Rosdolsky ${ }^{26}$, som primært beskæftiger sig med Grundrisse, men - hvilket er sagligt meget givtigt - i mange sammenhænge trækker Kapitalen med ind i problematikken, når der er »huller « $\mathrm{i}$ argumentationen i Grundrisse, er overgangen blot repeteret i form af det allerede overgangne. Rosdolsky ser udelukkende profitlæren (og herunder 'afledningen' af profitformen) som et svar på modsigelserne i den klassiske engelske $\varnothing$ konomis modsigelsesfulde bestemmelse af denne: ${ }^{27}$

»Medens Ricardos skole netop kørte fast i modsigelsen mellem værdibestemmelsen gennem arbejdet og den almene profitrate som en kendsgerning, så blev denne modsigelse udgangspunktet for Marx' nye profitlære«

Selvfølgelig er dette rigtigt, men dette »svar« overser blandt andet helt problemerne omkring profitformens introduktion netop på dette sted i Kapitalen. Man kunne med samme generelle rigtighed sige, at den marxske pengeteori er et svar på især Proudhons pengeteori, uden at man herved havde sagt noget som helst om grundlaget for den marxske pengeteori, nemlig udviklingen

25. I den marxistiske 'tradition' som ud fra Rosdolsky har forsøgt at præcisere den kapitallogiske fremstillingsforms specifikum har begrebet 'Das Kapital im Allgemeinen' haft en central betydning. Det har senere vist sig (se hertil f.ex. H-J Schanz: »Til rekonstruktionen af kritikken af den politiske $\varnothing$ konomis omfangslogiske status«, Århus 1973, og Birger Linde: Arbejdspapir om metodeproblemer i den marxistiske teori, ikke offentliggjort stencilat), at for det første er kapitalen i almindelighed ikke nogen overalt i det marxske forfatterskab (hvor bestemmelsen dukker op) entydigt fastlagt størrelse, og for det andet er kapitalen i sin almindelighed ikke dækkende for den almene kapitalteoris udsagnsområde: således må der i det mindste opereres med yderligere et logisk 'lag' (i Til Rekonstruktionen ... kaldt 'kapitalen i sin realitet i almindelighed'), som skal dække den almene logik for formerne for sammenstød mellem enkeltkapitaler, altså som skal formidle visse almene elementer i konkurrencen. Overgangen fra bind II til III må i denne her sammenhæng antages at kunne have en betydning for forholdet mellem kapitalen i sin almenhed og kapitalen i sin realitet i almindelighed, idet denne overgang sandsynligvis kan præcisere afledningen af den ene og den anden, således at vi ikke bare har et 'neben einander' af to logiske lag.

26. Roman Rosdolsky op. cit.

27. Rosdolsky, op. cit. pg. 439. 
af den simple værdiform til den almene værdiform ${ }^{28}$. Konkluderende siger Rosdolsky lapidarisk om begrundelsen for Marx' opgivelse af bl.a. Ricardos profitlære: ${ }^{29}$

»Vi ved nu, hvori »forkastelsen « af den tidligere profitlære bestod; (nemlig) i erkendelsen af profitten som en nødvendig »Erscheinungsform« for merværdien«.

Også dette er korrekt »definitorisk « repeteret, men intet er forklaret, hvilket tillige explicite kommer æstetisk frem ved at Erscheinungsform nu pludselig står i anførselstegn. Ganske rigtigt (iøvrigt en bestemmelse, som selv i denne svage formulering af Rosdolsky, står milevidt over, hvad største delen af postmarxismen har brygget omkring forholdet mellem profit og merværdi) er profitten merværdiens nødvendige Erscheinungsform (men ikke i anførselstegn), men denne nødvendighed må selv immanentisk afledes, den må forklares i sin nødvendighed. Det er ingenlunde tilstrækkeligt at hævde, at nu, hvor vi betragter merværdien i relation til den samlede kapital, er profitten opstået. At denne »logik « ikke er tilstrækkelig ses blandt andet af følgende ubesvarede spørgsmål: hvorfor betragter vi nu pludselig merværdien i forhold til den samlede kapital? Hvorfor ikke tidligere eller senere? Ejheller er det tilstrækkeligt for fremstillingen, at fastslå (hvor rigtigt det end er), at for kapitalisterne må det tage sig således $\mathrm{ud}^{30}$. Kapitalen går forud for kapitalisterne logisk set. Og det er allerførst denne, som med kategorial funktionslogisk nødvendighed $\mathrm{g} \varnothing \mathrm{r}$ disse kapitalister til karaktermasker, for hvem alt tager sig fordrejet ud. Det følger heraf, at det ikke er eller kan være kapitalisterne som uformidlede ideologiske subjekter, der igennem en (i øvrigt uforklarlig) akt forvandler merværdien til profit. Profitformen er ikke bare en ideologisk form, men kapitalisternes opfattelse af profitten som en ideologisk opfattelse (nødvendigvis falsk) forudsætter kapitalens konstitution of profitformen. Endvidere kunne vi gentage ovenstående spørgsmål i en lidt ændret form: hvorfor har vi nu pludselig at gøre med enkeltkapitalisterne? Hvorfor ikke før eller senere?

»... i denne helt fremmedgjorte profitform, og i samme grad som profittens gestalt tildækker dens indre kerne, får kapitalen mere og mere en saglig gestalt, bliver fra at have været et forhold mere og mere til en ting, men $^{31}$ en ting, som bærer det samfundsmæssige forhold i sig, som har slugt det, en ting som med fiktivt liv og selvstændighed forholder sig til sig selv ${ }^{32}$, et sanseligt oversanseligt væsen; og i denne form for kapital og profit dukker den op (erscheint es) som en færdig forudsætning på overfladen, det er dens form

28. Selvfølgelig er dette ikke den hele marxske pengeteori, det afgørende i denne her sammenhæng er, at ved værdiformsproblematikken grundlægges pengeteorien.

29. Rosdolsky, op. cit., pg. 440.

30. Det må måske understreges igen, at når der her opereres med »utilstrækkeligheder « så forudsættes hele tiden en immanentisk rekonstruktionsintention. Hvis ikke dette er tilfældet, så kan alt og intet være »tilstrækkeligt $\ll$.

31. Sml. fodnote 5 her.

32. Sml. Grundrisse pg. 631-632, ikke medtaget i Rhodos »Grundrids«-udvalg. 
for virkelighed eller bedre dens virkelige existensform. Og det er den form, hvori den lever og afspejler sig i bevidstheden hos dens bærere, kapitalisterne $\ll^{33}$.

I Grundrisse hedder det om profitformens nødvendighed: ${ }^{34}$

»Forvandlingen af merværdi til profitformen, denne art af beregning af merværdien gennem kapitalen, hvormeget den end beror på en illusion om merværdiens natur (eller snarere tildækker den), er nødvendig ud fra kapitalens standpunkt «.

Omend Marx her heller ikke siger noget om, hvorfor denne form er nødvendig, så gør han det i det mindste klart, at formen ikke primært eller exklusivt kan afledes ud fra kapitalisternes standpunkt ${ }^{35}$. Og - for at afslutte denne foreløbige argumentation - det, som kommer til syne, beror ikke bare på en forvridning i receptionen af forholdet: ${ }^{36}$

»Varernes gennemsnitspris ikke blot synes at være forskellig fra deres værdi, den er her faktisk forskellig fra deres værdi, altså det arbejde, der er realiseret i varen, og en individuel kapitals gennemsnitsprofit er forskellig fra den merværdi, som denne kapital har ekstraheret af de arbejdere, den beskæftiger«.

En forklaring af profitten som merværdiens nødvendige form for tilsynekomst, der går ud fra en ideologikritisk orienteret afledning af forholdet fra kapitalisternes funktionsbevidsthed, er derfor ikke nogen forklaring, og ikke bare er den ikke nogen forklaring: tillige kan en sådan ansats fuldstændig fordreje profitformens status.

Hos Reichelt måtte man derimod forvente et svar på det spørgsmål vi stiller, idet han som arbejdsprogram formulerer dette, at kunne bidrage til en klarificering af de dialektiske overgange, som enten direkte er hos Marx eller som latent må siges at have været af betydning for kompositionen af kritikken af den politiske økonomi, men som Rosdolsky, ifølge Reichelt, blot referere: ${ }^{37} 3$

»Endskønt han (Rosdolsky, H-JS) siger om Grundrisse, - at netop dette værk viser os, hvorledes »opbygningen af den marxske Kapital helt igennem er dialektisk «, så forbliver dette til syvende og sidst en ren forsikring. En af svaghederne i hans bog består især i, at han overalt gør opmærksom på brugen af hegelske kategorier samtidig med, at han så godt som ukommenteret gengiver hele passager, der udmærker sig ved at virke som højest spekulative formuleringer, og derfor netop er interpretationsbehøvende $\ll$.

33. Marx: »Theorien über den Mehrwert«, III, MEW bind 26.3, pg. 474. Overgangen til »Kapitalens tredie bog « i Grundrisse indeholder som nævnt elementer, som næsten er identiske med beskrivelsen her fra Theorien. Hvad der er centralt er dette: i modsætning til Kapitalen gør Marx det her klart, at profitten ikke konstitueres ud fra enkeltkapitalerne eller enkeltkapitalisternes bevidsthed.

34. Grundrisse, pg. 653; ikke medtaget i Rhodos »Grundrids«-udvalg, fremhævelse af H-J S.

35. Sml. planskitsen i Grundrisse pg. 175; Grundrids bind I, pg. 163, Modtryk og Kurasje, Århus 1974. Her ses, at kapitalisterne først dukker op et godt stykke efter, at profitformen er blevet introduceret.

36. Das Kapital III, MEW 25, pg. 837; Kapitalen, 3. bog 4, pg. 1067.

37. Helmut Reichelt, op. cit., pg. 14. 
Reichelt har ret i denne dom, men hvordan ser sagen ud, når vi tager hans eget fors $\varnothing$ g. Da han primært beskæftiger sig med Kapitalens tre første kapitler ${ }^{38}$, kan man ikke med rimelighed forlange en gennemarbejdet bestemmelse af afledningsforholdet mellem merværdi og profit, men at der hos Reichelt så at sige intet siges om denne afledning udover, at leddene merværdiform-profitform findes som inventar i de to grundklasser inden for kapitaliogikken (som Reichelt opererer med), nemlig das Kapital im Allgemeinen og das Kapital in seiner Realität, er udtryk for, at vi ikke er kommet videre end Rosdolsky, i det mindste, hvad det her behandlede problem angår.

Man vil hos Reichelt intet finde om denne overgangs problem; hvad man finder en række punktuelle og vigtige dechiffreringer af præsentationslogiske forhold vedrørende profitformen. Dette betyder tillige, at hans rekonstruktion af forholdet mellem, eller rettere sagt: afledningen af das Kapital in seiner Realität fra das Kapital in Allgemeinen forbliver mangelfuld. Manglerne centrerer sig omkring den kontinuerlige afledning (og herunder bestemmelse) af denne overgang. Han beskriver (som vel nok den første efter Marx) den logiske statusforskel de to lag imellem, og han fastholder overfor Rosdolsky med rette, at das Kapital im Allgemeinen ikke bare er en fremstillingslogisk figur, men et realforhold (omend ikke et empirisk forhold). Rosdolsky svinger her, til der hævder han forholdets realstatus, til andre tider opgiver han dette.

I det Reichelt ikke immanentisk afleder det ene logiske lag af det andet (i det problemfelt, som her er på tale), så implicerer dette tillige, at han intet svar giver på overgangen fra reproduktionslogikken (i II. Kapitalbind) til profitformen (i III. Kapitalbind) ${ }^{39}$.

38. Som nævnt, så koncentrerer Reichelt sig om Kapitalens tre første kapitler. En sådan indskrænkning er selvfølgelig både mulig og meningsfuld, imidlertid kan en sådan indskrænkning let få et anstrøg af overakcentuering af formbestemmelserne på bekostning af materialitetsformerne: netop i de første tre kapitler spiller materialitetsformerne ingen rolle for de økonomiske formbestemmelser, men dette ændres i Kapitalens udvikling. Uden her at ville uddybe dette nærmere vil jeg hævde, at Reichelts bog netop på grund af elimineringen af materialitetsformsproblematikken (der igen kan ses som en effekt af stofbegrænsningen') lider af en på visse måder forkert overpointering af kapitalformerne.

39. Vi har tidligere (sml. fodnote 24) været inde på vanskelighederne omkring forholdet mellem das Kapital im Allgemeinen og das Kapital in seiner Realität (im Allgemeinen). Reichelt er klar over denne vanskelighed, og han er klar over, at Marx i de kategoriale udtalelser (planskitser, indskudte kommentarer etc.) ikke er entydig: f.ex. er konkurrencens status samt differentieringer indenfor konkurrencebegrebet yderst svingende. Det er tesen i denne her artikel, at man ikke kan løse problemerne omkring det reale indhold i disse »svingninger « samt muliggøre en analytisk anvendelig distinktion omkring de to kapitallag, sålænge man bliver stående ved disse kategoriale udtalelser: når disse engang et indset at være såvel interpretationsbehøvende som 'svingende', så er der kun en vej frem (og denne ligner i allerhøjeste grad vejen frem fra de historieteoretiske almene udsagn i de forskellige indledninger), nemlig at gå i lag med den materielle fremstilling selv, kun denne vil muligvis kunne klarificere sagsforholdet. Og her er der som nævnt - mangler hos Reichelt. Men ikke bare hos Reichelt: det karakteriserer så godt som alle forsøg på at pointere kapitallogikkens status ud fra begrebet das Kapital im Allgemeinen, at der blives stående ved de kategoriale udtalelser af Marx uden at hans egen fremstilling selv inddrages. En sådan mangel findes i bogen »Til rekonstruktionen af kritikken af den politiske 
Vi er tilbage ved Marx, og vi fastholder relevansen af vort spørgsmål om overgangens natur og nødvendighed.

V

For at komme på sporet af et begrundende svar på spørgsmålet omkring den i første omgang påstandsagtige udtalelse (fra Marx) om profitten som merværdiens nødvendige Erscheinungsform, samt en begrundelse for profitformens optagelse umiddelbart efter reproduktionsproblematikken, kan vi stille følgende spørgsmål: hvad er det for en modsigelse i reproduktionen, således som denne immanentisk rigtigt blev fremstillet i II. Kapitalbind, som dels gфr kapitalen indenfor mervardiformen realiter reproduktiv umulig, og som med logisk (kapitallogisk) nфdvendhed fremtvinger konstitutionen af profitformen, som den alene mulige form, hvori modsigelsen kan bevage sig?

Vi ved, at Marx opstiller ligevægtsbetingelserne for en simpel og udvidet reproduktion i II. bind indenfor das Kapital im Allgemeinen. Igennem en kritisk gennemgang af især II. Internationales bestemmelse af disse reproduktionsskemaers status i almindelighed og deres betydning for en kriseteori i særdeleshed kan det vises ${ }^{40}$, at man ingenlunde kan tage disse ligevægtsbetingelser som a) de facto udtryk eller b) som Marx' sidste ord, hvad realisationsproblematikken indenfor reproduktionen angår ${ }^{41}$. Vi ved også, at II. Kapitalbind bl.a. skal behandle »die Bedingungen « for forefindelsen af nødvendige reproduktionselementer for den i samfundet stedfindende produktion.

Det centrale i tesen her er, at med introduktionen af reproduktionslogikken og herunder opstilling af ligevægtsbetingelser, kommer forudsætningerne for ligevægtsbetingelserne (i kapitallogikken, endnu er realkapitalen irrelevant), således som disse sættes (i fremstillingen) uden selv immanentisk at være sat af kapitalen, i modsætning til merværdiproduktionen selv. Eller sagt på en anden måde: med reproduktionslogikken nås merværdiformens objektive grænse, ikke

$\emptyset$ konomis omfangslogiske status « og i omtalte arbejdspapir af Birger Linde: i dette demonstreres, på grund af den der udfoldede minutiøse 'filologiske' analyse, at der egentlig ikke kan præciseres ret meget ud fra de kategoriale udtalelser omkring det kapitallogiske forhold mellem disse lag. Hvad den filologiske analyse kan (og det er ikke uvæsentligt) er, at vise, at de fleste 'simple' løsninger af forholdet er i modstrid med Marx' selvforståelse.

40. Der er efterhånden udkommet en lang række undersøgelser over og kritikken af II. Internationales reception af II. Kapitalbinds reproduktionsskemaer. Den vel endnu bedste findes i omtalte værk af Rosdolsky, dog kun i 1. oplag: »Der Streit um die Marxschen Re-Reproduktionsschemata«, op. cit., pg. 524-597. Paul Mattick leverer i forbindelse med en kritik af Mandels »Der Spätkapitalismus « en kritik af Rosdolskys bestemmelse af disse reproduktionsskemaers status, se artiklen: »Ernest Mandels 'Spätkapitalismus' « i Paul Mattick: Kritik der Neomarxisten, Frankfurt/M, 1974, især pg. 142-145.

41. Dette synes Lenin at mene i polemikken mod narodnikierne i værket om kapitalismens udvikling i Rusland. 
således at forstå, at merværdien hermed forsvinder, men således, at merværdiformen (og hermed værdibestemmelserne) nødvendigvis må konstituere en ny form, for reproduktivt at kunne bevæge sig (altså enhed af valorisering og reproduktion). Denne nye form er profitformens (og hermed prisbestemmelserne ${ }^{42}$ ).

Men hvorfor nås merværdiformens objektive grænse $\mathrm{i}$ reproduktionslogikken?

»Sålænge vi betragtede værdiproduktionen og kapitalens produktværdi individuelt ${ }^{43}$, var vareproduktets naturalform ganske underordnet for analysen, om produktet f.eks. bestod af maskiner eller korn eller spejle. Det var altid kun eksempler, og en hvilken som helst produktionsgren kunne lige så godt som en anden tjene som illustration. Det vi havde med at gøre var den umiddelbare produktionsproces selv, der overalt fremtræder som en individuel kapitals proces ${ }^{44}$. For så vidt der var tale om kapitalens reproduktion, var det tilstrækkeligt at forudsætte, at den del af vareproduktet, som repræsenterer kapitalværdien, inden for omsætningssfæren ville finde lejlighed til igen at forvandle sig til sine produktionselementer og dermed atter tage form af produktiv kapital. Det var også tilstrækkeligt at forudsætte, at arbejder og kapitalist på markedet ville forefinde de varer, som de giver arbejdsløn og merværdi ud til. Denne rent formelle fremstillingsmåde er

42. Omend dette ikke er stedet til en gennemgang af det marxske prisbegreb, bl.a. fordi dette helt ville sprænge rammerne for arbejdet her, så skal det lige nævnes, at der med prisbestemmelse her ikke bare menes det, som Marx siger i forbindelse med pengeformen i III. kapitel i første bind, og som fastholdes som prisbegreb I. og II. Kapitalbind - nemlig, at prisen er værdien målt i penge. Af denne 1. prisbestemmelse fremgår, at der ikke kan være nogen kvantitativ inkongruens mellem værdimassen og dennes prisudtryk: de to forhold kan udtrykkes i forskellige målestokke, men i denne 1. prisform vil der altid være proportionalitet samt kongruens de to størrelser imellem. Dette er ikke længere tilfældet ved den prisform, som opstår efter profitformen (produktionsprisformen), som netop udmærker sig ved, at værdimasse og prisstørrelsen kun for den samfundsmæssige totalst $\varnothing$ ttelse af begge er kongruente; en udmærket gennemgang af prisformsproblematikken findes i Bernd Koch's: »Weltgeld und Wertgesetz« endnu ikke offentliggjort dipolomarbejde, Otto Suhr Instituttet, West Berlin. Når det her kan have betydning at henvise til dette arbejde, så fordi det (efter Kochs udsagn) om kort tid vil blive offentliggjort i tidsskriftet »Mehrwert $\ll$.

43. Egentlig er udtrykket 'individuelt' her misvisende, der burde have stået 'umiddelbart' fordi den hidtidige fremstilling (nemlig I. Kapitalbind plus II. Kapitalbind frem til afsnittet omkring reproduktionen) netop ikke har været generaliserende ud fra de i den empiriske realitet foreliggende enkeltkapitaler, men derimod har den blotlagt de for enhver kapitalproduktion konstituerende forhold. At det kan have betydning her at gøre opmærksom på dette skyldes bl.a., at man i II. Internationale (og især i forbindelse med den såkaldte reproduktionsproblematik) faktisk gik ud fra, at første og andet bind handlede om det generelle for enkeltkapitaler. Gælder dette (som man antog) så er de problemer, som man mener, at reproduktionsafsnittet skal belyse, tillige helt forskellige fra dem, de skal belyse i den autentiske marxske fremstilling. Hvis den forudgående analyse beskæftiger sig med det generelle for enkeltkapitaler, så er man tillige fremme ved det empiriske realitetsplan, og derfor er reproduktionsskemaernes udsagn, eller de betingelser, som her oparbejdes, også direkte empirisk relaterbare.

44. Atter den samme upræcished i begrebet som ovenfor. Tillige tilføjer den danske oversættelse endnu én: hos Marx står der: »...als Prozess eines individuellen Kapitals sich darstellt«, i den danske oversættelse anvendes her for 'sich darstellt' udtrykket 'fremtræder'. Imidlertid kan fremtrædelsestermen her forvirre, idet den (i de $\varnothing$ vrige sammenhænge, hvor den bruges) ellers er udtrykket for 'erscheinen'. Og den umiddelbare produktionsproces er afgjort ikke nogen 'Erscheinung'. 
ikke længere tilstrækkelig, når vi betragter samfundets totalkapital ${ }^{45}$ og dens produktværdi. At en del af produktværdien igen forvandles til kapital, at en anden del indgår såvel i kapitalistklassens som i arbejderklassens individuelle forbrug, dette danner en bevægelse inden for selve den produktværdi, der er resultatet af totalkapitalen. Denne bevægelse er erstatning, ikke kun værdimæssig, men stoflig, og den er derfor lige så meget betinget af indbyrdes relationer mellem samfundsproduktets værdibestanddele som af deres brugsværdi, deres stoflige skikkelse $\ll^{46}$.

Heraf fremgår, at merværdiproduktionen (i den kapitallogiske fremstilling) nu for første gang konfronteres med produktionsprocessens dobbeltkarakter af værdi og brugsværdi ${ }^{47}$. For første gang (ser vi bort fra distinktionen mellem fix og flydende kapital) træder naturalformen ikke blot ind i kapitalen som en permanent randbetingelse, som en forudsat betingelse, men som en betingelse, der på engang skal styres selv af kapitallogikken, det vil sige, at denne skal sætte materialiteten i dennes (for kapitalen) nødvendige differentiering samtidig med at materialiteten aldrig som sådan 'kan gå op i’ kapitalen, blive identisk med denne.

Omend kapitalen ikke kan defineres, men kun udvikles og afledes, så siges adskillige steder i Kapitalen og Grundrisse, at kapitalen primært er bestemt som en sig selv valoriserende værdi (sich verwertender Wert). Dette udsagn rummer bl.a. elementer, som siger, at kapitalens mål er produktion af kapital (eller merværdi), og at kapitalen i denne dens telos kategorialt er absolut mobil: da dens telos er værdiforøgelse optræder naturalformerne kun som nødvendige betingelser:

»kapitalen er i og for sig (an und für sich) ligegyldig over for enhver produktionssfæres specificitet (Besonderheit), og bestemmes kun gennem den større eller mindre vanskelighed i salget af varerne fra denne eller hin produktionssfære, hvor den er anlagt, samt hvorledes den anlægges, og i hvilket omfang den vandrer fra en produktionssfære over i en anden, eller hvorledes den ændrer fordelingen mellem de forskellige produktionssfærer ${ }^{48}$

45. 'Totalkapital' på tysk Gesamtkapital angiver her blot den samlede produktive, endnu ikke i enkeltkapitaler opsplittede kapital. Udtrykket 'totalkapital' er derfor en uheldig oversættelse, da der således ikke kan skelnes mellem Gesamtkapital (som bestemt ovenfor) og så III. Kapitalbinds 'totalkapital', som netop ikke længere begrænser sig til den produktive kapital inddelt i to sektorer. Man kunne hertil føje, at der i den dialektiske terminologi, som Marx helt klart anvender, skelnes mellem 'gesamt' og 'Totalität', hvor 'gesamt' groft sagt angiver enheden, som forstandsmæssigt er ved at blive differentieret, hvorimod 'Totalität' står for den igennem sig selv fuldstændig uddifferentierede enhed.

46. Marx: Das Kapital II, MEW bind 24, pg. 393; Kapitalen, 2. bog 2, pg. 507-508. Det lange citat er begrundet ved, at Marx her måske mest kondenseret i hele Kapitalen gør rede for brugsværdiens betydning, samtidig med at han her kategorialt viser, hvorledes brugsværdien 'trækkes ind' $i$ analysen.

47. I I. Kapital bind findes et kapital, som hedder 'Simpel reproduktion' (det 21. kapitel). Imidlertid er der dér ikke tale om en inddragelse af materialiteten: den simple reproduktion skal der udtrykke den rene form-reproduktion, der fungerer som en automatisk repetitiv proces, når først arbejdskraften har antaget vareform: arbejdslønnen (lønarbejdet) er her garantien for at arbejdskraften uden extraøkonomisk tvang permanent vil reproducere sig i vareform. I II. Kapitalbind vises derimod, at den rene formreproduktion ikke slår til.

48. Marx: Resultate des unmittelbaren Produktionsprozesses, Frankfurt/M, 1970, pg. 39, fremhævelse af Marx. 
Hidtil har Marx kunnet forudsætte den gnidningsfrie vandring fra sfære til sfære samt betingelserne for realisationen af de forskellige kapitalers vareprodukter, det vil sige, at hidtil er såvel de kvantitative som kvalitative betingelser for realisationen på markedet (i cirkulationen) blevet forudsat. Imidlertid er den kapitalistiske produktion karakteriseret ved at være uden nogen samfundsmæssig bevidst styring. Hvis det derfor gælder, at kapitalen er en sådan sig selv valoriserende værdi og der realiter (og ikke bare som et empirisk overfladeforhold) gælder, at der findes visse betingelser (såvel kvantitative som kvalitative) for dens reproduktion igennem markedet, så må det vises, at kapitalen selv kan skabe betingelserne for forefindelsen af disse reproduktivt nødvendige betingelser: umuligheden af den samfundsmæssige styring udelukker, at der skulle være en anden instans som 'skænkede' kapitalen disse reproduktive betingelser.

I reproduktionsproblematikken åbnes den egentlige diskussion vedrørende betingelserne for denne forefindelse af betingelser, eller rettere: det bestemmes, hvilke helt basale betingelser der må forudsættes for en reproduktion.

Det karakteristiske for de indikatorer Marx nu opstiller for muligheden af en (harmonisk) reproduktion er, at disse koncentrerer sig om a) stoflig erstatning, b) værdimæssig erstatning og c) ækvivalensformidlingen som medium for de to arter af erstatning. Reproduktionen analyseres således i første omgang ud fra erstatningsaspektet. Vi kender denne undersøgelses resultat. Hvad der imidlertid er af vigtighed at fastholde, er, at selv om såvel den stoflige som den værdimæssige erstatning er conditio sine qua non for en kapitalistisk reproduktion (hvadenten denne er simpel eller udvidet), så er hverken den værdimæssige eller den stoflige erstatning kapitalens mål. Disse er kun betingelser, omend nødvendige. Vi ser altså, at betingelserne for forefindelsen af reproduktionsn $\varnothing$ dvendige elementer og lovmæssigheder på engang er nødvendige og samtidig forskellige fra kapitalens mål ${ }^{49}$.

Vi kan nu formulere vores tese til forklaring af den nødvendige overgang fra reproduktionen til profitformen således: reproduktionens erstatningslogik, som udvikles igennem merværdi og værdiformer (men tillige med henblik på den stoflige erstatning og ækvivalensformidlingen) står nødvendigvis i modsætning til reproduktionens Verwertungslogik. Profitformen er da den form, hvori alene denne modsætning kan bevæge sig.

Men hvorfor existerer denne modsætning i reproduktionslogikken i II. Kapitalbind ${ }^{50}$ ? Vi har allerede været inde på nødvendigheden af inddragelsen af stofsiden $^{51}$ for i det hele taget at kunne stille et nok så abstrakt reproduktionsspørgsmål. Herved aktualiseres de materielle komponenters $\emptyset$ konomiske formbestemmelser, og herved bliver merværdiformen som form for det samfundsmæssige merprodukt umulig som reproduktionsmedium. Marx undersøger i

49. Se hertil das Kapital III, MEW 25, pg. 260; Kapitalen, 3. bog 2, pg. 329-330.

50. Se hertil das Kapital III, MEW 25, pg. 162; Kapitalen, 3. bog 1 pg. 200.

51. Dette var iøvrigt allerede Quesnay klar over i sin »Analyse du Tableau économique« 1766. 
II. Kapitalbind reproduktionen ud fra en sektoral inddeling, som blandt andet opstår igennem to arter af materialiteters forskellige økonomiske formbestemmelse: produktion af produktionsmidler og produktion af konsummidler. Ser vi en overgang bort fra denne reproduktionslogiks erstatningsside og ligevægtsbestemmelserne for denne, så kan vi hurtigt konstatere, at den materielle forms indflydelse på de økonomiske formbestemmelser tillige fremtvinger reproduktive valoriseringsvanskeligheder; alene stofsiden, som relateret til arbejdsprocessen, viser: at der af teknologisk-materielle grunde må findes så forskellige organiske sammensætninger, at der af stoflige grunde (forskelle i de respektive fixe kapitalers materialitetsformer) må findes så mange differenser mellem givne kapitalers totale omslagstider, at der af stoflige grunde må findes så mange og store forskelle i den årlige merværdimasse per anvendt produktiv kapital, at alene af disse grunde (som kan præciseres og udvikles yderligere) ville merværdiproduktionen indenfor en reproduktionssammenhæng, som udelukkende er bundet til værdi- og herunder merværdibestemmelser være ganske umulig, da kapitalen som en (ud fra sit immenante telos) sig selv blot valoriserende værdi netop kategorialt er indifferent overfor, hvad den producerer og hvor meget den producerer, men kun 'interesseret i' hvor meget den valoriserer sig, samtidig med, at valoriseringen reproduktivt er bundet til betingelser, der i hvert fald indenfor visse grænser kræver en bestemthed i såvel 'hvad' som 'hvor meget' der produceres ${ }^{52}$.

Men herved er der opstået en modsætning mellem a) kapitalen som kategorialt absolut mobil og primært en blot sig selv valoriserende værdi og b) nødvendigheden af existensen af betingelser for reproduktionen, som skulle kunne indløse eller muliggøre denne valorisering: ikke bare sættes disse betingelser ikke automatisk igennem merværdiproduktionen, nej disse betingelser kan ikke sattes igennem merværdiformen som den afgørende form for merproduktet.

Erstatningslogikken (som vi tidligere var inde på) er kun et (omend vigtigt) aspekt heraf, men det siger, at den stoflige (og hermed den værdimæssige) erstatning står i modsætning til valoriseringslogikken, eftersom valoriseringslogikken dels er indifferent overfor stofsiden og dels limiteres specifikt af denne samtidig med at mulighedsbetingelsen for den samfundsmæssige reproduktive valorisering er knyttet sammen på en sådan måde, at den permanent må forudsætte bestemte stoflige kvaliteter og kvantiteter; eller: ligegyldigt hvor meget der end produceres værdi og merværdi, det vil sige at rigdommen har antaget den abstrakte form, så vil der stadig existere en nødvendig fordeling af det samfundsmæssige arbejde, og ikke bare som en rammebetingelse for samfundets opretholdelse rent abstrakt bestemt, men samtidig som en betingelse for selve værdiproduktionen:

»Vrøvlet om nødvendigheden af at bevise værdibegrebet beror blot på den totale uvidenhed, såvel hvad angår den sag, som det drejer sig om at bestemme, som hvad hvad angår

52. Se hertil f.eks. das Kapital III, MEW 25, pg. 165-167; Kapitalen, 3. bog 1, pg. 202-204. 
den videnskabelige metode. At enhver nation ville gå tilgrunde, som - jeg vil ikke sige et år, men blot et par uger - indstillede arbejdet, ved ethvert barn. Ligeledes ved det, at massen af produkter til opfyldelse af de forskellige behov nødvendigg $\varnothing$ r forskellige og kvantitativt bestemte masser af det samfundsmæssige arbejde. At denne nødvendighed af en fordeling af det samfundsmæssige arbejde i bestemte proportioner ikke på nogen måde ophæves igennem den bestemte form for den samfundsmæssige produktion, men at denne kun ændrer hins måde at komme til syne og funktionere på (erscheinungsweise) er self-evident. Naturlove kan overhovedet ikke ophæves. Hvad der alene, under forskellige historiske tilstande, kan forandre sig, er formen, hvori disse love sætter sig igennem ... Vulgærøkonomen har ikke den ringeste anelse om, at de virkelige, daglige bytteforhold og værdistørrelserne ikke kan vare umiddelbart identiske ${ }^{53}$. Vitsen ved det borgerlige samfund består jo netop i, at der a priori ikke findes nogen bevidst samfundsmæssig regulering af produktionen. Det fornuftige og naturnødvendige sætter sig igennem som et blindt virkende gennemsnit « ${ }^{54}$,

og netop denne 'sætten sig igennem' af den nødvendige fordeling af det samfundsmæssige arbejde (nødvendig såvel for dette kapitalistiske samfunds opretholdelse rent fysisk som for dets opretholdelse af de værdiproduktionsmæssige betingelser) kræver en form, som muligg $\emptyset r$ dette.

De materielle faktorers formøkonomiske effekter på merværdimassen (og årlig rate), vil, sålænge kun merværdiformen haves, betyde, at kapitalen i forbindelse med sin valoriseringstrang nødvendigvis må ophæve sine reproduktionsbetingelser.

Alene af denne grund kan II. Internationales omgang med de marxske reproduktionsskemaer afvises. Hvis kapitalens endelige reproduktionsform kunne være bundet alene til værdi- eller merværdiformen, så ville der ikke existere nogen kapital, idet den permanent ville foreligge i en uoverstigelig modsætning mellem reproduktivitets- og profitabilitetsbetingelser ${ }^{55}$.

Merværdiformen er umulig som formidlingsform for en reproduktion, som tendentielt både skal sikre en 'proportionate production' og en 'profitability'. Profitformen (herunder almen profitrate, produktionspriser, markedsproduktionspriser etc.) er derfor »svaret« på den specifikke modsigelse, som ligger i II. Kapitalbinds reproduktionsskemaer ${ }^{56}$.

Når tredie Kapitalbind derfor starter med profitformen, så er dette et udtryk for, at denne alene er den form, hvori reproduktionens modsætninger kan bevæge sig. Når Marx i begyndelsen af III. bind siger: ${ }^{57}$

53. Vi ser her, at Marx netop pointerer umuligheden af den reproduktive identitet mellem værdistørrelse og prisstørrelse. Heri ligger emplicite et argument for reproduktionens logiske umulighed indenfor værdi- og merværdiformen.

54. Marx. brev til Kugelmann, 11. juli 1868, Briefe über das Kapital, pg. 184-185; se hertil Ole Marquard: »Om nogle af dialektikbegrebets indhold', stencilat, idehistorisk institut, Århus Universitet, marts 1974 .

55. Se hertil Grundrisse, pg. 647-648, ikke modtaget i udvalget Grundrids; Rhodos.

56. Se hertil das Kapital III, MEW 25, pg. 205-206; Kapitalen, 3. bog 1, pg. 253-254.

57. Das Kapital III, MEW bind 25, pg. 333; Kapitalen, 3. bog 1, pg. 36. 
»Det, det drejer sig om i denne tredie bog, kan ikke være at anstille generelle betragtninger over denne enhed (mellem produktionsproces og cirkulationsproces, H-JS). Tværtimod, det drejer sig om at finde frem til og beskrive de konkrete former, der vokser frem af kapitalens bevagelsesproces, betragtet som en helhed «,

så ligger heri tillige, at denne 'kapitalens bevægelsesproces, betragtet som helhed' selv har visse betingelser, som netop ikke kan forudsættes. Desværre pointeres dette ikke hols Marx.

Med profitformen er modsætningen mellem de stoflige differenser, for så vidt som de får $\emptyset$ konomisk form bestemmende effekter, og kapitalen som en sig selv valoriserende værdi ikke ophævet ${ }^{58}$, modsætningen er konserveret i en bevægelig form. Og denne nye bevægelsesform, som tillige er, som Marx adskillige gange fastslår det, kapitalens »wirkliche Existensform $«{ }^{59}$, er endvidere grundlaget for nye og potentielt systemsprængende modsætninger. Når det hedder, at disse nye modsætninger for første gang tillige er potentielt systemsprængende i modsætning til de forudgående modsætninger, så hænger dette sammen med, at vi først nu får 'et system', og derfor også først muligheden for 'systemsprængende' modsætningsformer. Som bekendt er profitratefaldet den vigtigste af disse.

Hermed skulle det være vist hvorfor profitformen er merværdiens nødvendige 'Erscheinungsform'. Tillige er hermed al snak om profitten som en primært ideologisk kapitallegitimerende og mystificerende størrelse afvist; hvorved der ikke er sagt, at ikke netop profitformen virker legitimatorisk. Det afgørende er blot, at profitformen ikke kan afledes af sine ideologiske effekter.

Profitformen er hermed basalt en distributionsform for merværdien i relation til den samlede kapital, en distributionsform som udsletter (i sine udtryk) merævrdiproduktionen (eller bredere: værdiproduktionens kilder) samtidig med og det er det afgørende i denne her sammenhæng - at denne distributive formidling af værdi- og merværdiproduktionen alene muligg ør denne i en reproduktionssammenhæng. ${ }^{60}$

Profitformen muliggør således en distribution af merværdien på en sådan måde, at merværdiproduktionen er mulig igennem kapitalen som en sig selv valoriserende værdi på trods af, at denne kvalitet ved kapitalen umiddelbart står i modsætning til den samfundsmæssig nødvendige fordeling af arbejdet. Profitformen er da den form, hvorigennem alene »det fornuftige og naturnødvendige (kan sætte) sig igennem som et blindt virkende gennemsnit ${ }^{61}$. Når Marx bl.a. i Grundrisse siger, at:

58. De to arter af betingelser dukker bl.a. op i form af to krisetyper: realisations- og profitabilitetskriser, eller i form af overproduktion af varer/underkonsumtion af varer og overakkumulation af kapital.

59. Se f.eks. Theorien über den Mehrwert III, MEW bind 26.3, pg. 474. I øvrigt er denne bestemmelse omkring profitformen, som den form, hvor kapitalen vinder sin virkelige existensform eller sin egentlige virkelighed begrundende for valget af udtrykket: 'kapitalen i sin realitet i almenhed' i bogen »Til rekonstruktionen af kritikken af den politiske $\emptyset$ konomis omfangslogiske status $\ll$.

60. Se Theorien über den Mehrwert III, MEW bind 26.3, pg. 474.

61. Briefe über das Kapital, pg. 185. 
»Den samlede merværdi, på samme måde som den samlede profit, der blot er mervardien beregnet på en anden måde, kan aldrig vokse gennem denne operation, ejheller aftage; det er ikke massen selv, men derimod dens fordeling mellem de forskellige kapitaler som herved modificeres ${ }^{62}$,

så skal det tilføjes, at dette egentlig er en trivialitet (nemlig kvantitetens indifferens over for sin distribution), og at profitten (profitformen) ikke bare er en de facto fordelingsform af merværdien, men at denne fordelingsform, som muligg $\varnothing$ res igennem profitformen, tillige er betingelsen for merværdiproduktionen selv. Profitten er da ikke blot en de facto effekt af merværdiproduktionen, men dennes nødvendige bevægelsesform. De virkelig afgørende »erscheinungsformer « hos Marx er altid tillige bevagelsesformer. Bevægelsesformer for modsætninger.

$\mathrm{Vi}$ begyndte artiklen med en problematisering af forholdet mellem kapitalens præsentationslogik og dens afledningsform. Omkring bestemmelsen af profitten som merværdiens nødvendige 'Erscheinungsform' skulle det være demonstreret, hvor vigtigt det er at fastholde ikke-identiteten af disse to: hvis man nemlig blot repetitivt fastslår, at profitten er merværdiens måde at komme til syne på, så har man endnu overhovedet ikke begrundet noget som helst. Man kan ganske vist henvise til karaktermaskernes beregninger, men disse er dog ellers højest usikre sandhedsvidner. Kun den immanente afledning kan begrunde nødvendigheden af en given (og da netop altid specifikt begrundet) måde, hvorpå kapitalen kommer til syne.

62. Grundrisse pg. 646, fremhævelse af Marx; ikke medtaget i udvalget Grundrids; Rhodos.

\section{Subskription på grundrids}

Karl Marx: Grundrids til kritikken af den politiske økonomi. 4. bind, ialt ca. 1100 sider. Udgivet sammen med Forlaget KURASJE. Oversættelse, noter og indledning ved Hans-Jørgen Schanz og Mihail Larsen.

Bogladeprisen for hele værket bliver, beregnet ud fra det nuværende prisniveau, ca. 180 kroner, men hele værket kan forudbestilles ved at indbetale 150 kroner til MODTRYK. Første bind vil derefter straks blive tilsendt og de resterende 3 bind vil iflg. planen udkomme foråret 75 , efteråret 75 og foråret 76 . Har du allerede købt første bind, kan de sidste 3 bind forudbestilles til favørpris ved at du indbetaler 100 kroner til MODTRYK. Subskribenter, der tidligere har udnyttet mere favorable subskriptionstilbud får selvfølgelig værket tilsendt til den oprindeligt aftalte pris.

\section{Forlaget MODTRYK}

Anholtsgade 4, 8000 Århus C.

Postgiro 5216478 . Telefon (06) 127912 